\title{
Optimasi Formulasi Esens Sheet Mask Kombinasi Ekstrak Spirulina platensis dan Nanopartikel Bentonit dengan Metode Simplex Lattice Design
}

\section{Optimization of Sheet Mask Essence Formulation Containing Extract of Spirulina platensis and Bentonite Nanoparticles using Simplex Lattice Design}

\author{
Erindyah Retno Wikantyasning*, Ulil Fikri Nurhakimah, Ramadhani Dwi Sula, Kartika Fidi Astuti \\ Fakultas Farmasi, Universitas Muhammadiyah Surakarta, Jl. A. Yani Tromol Pos 1 Pabelan, Kartasura, \\ Sukoharjo, 57162, Indonesia \\ *E-mail: erindyah.rw@ums.ac.id
}

\begin{abstract}
Abstrak
Spirulina platensis diketahui memiliki aktivitas antioksidan melalui kandungan zat warna biru spirulina yang disebut dengan fikosianin. Bentonit mengandung berbagai mineral yang dapat menyerap air dan diketahui memiliki kemampuan sebagai matriks peredam radikal bebas. Penelitian ini bertujuan untuk mendapatkan formula optimum esens sheet mask kombinasi ekstrak Spirulina platensis dengan kombinasi nanopartikel bentonit dan mengetahui aktivitas antioksidan dari formula dengan metode penangkapan radikal bebas menggunakan DPPH (2,2-difenil-1-pikrihidrazil). Pembuatan nanopartikel bentonit dilakukan dengan metode High Energy Milling (HEM) dan dikarakterisasi menggunakan Particle Size Analyzer (PSA). Hasil karakterisasi nanopartikel diperoleh ukuran partikel 152,8 $\pm 0,69 \mathrm{~nm}$ dan nilai PI 0,106 $\pm 0,03$. Uji stabilitas fisik menunjukkan sediaan seragam, viskositas antara 0,7-1,1 dPas, dan $\mathrm{pH}$ antara 5-6,5. Nilai $\mathrm{IC}_{50}$ antioksidan ekstrak Spirulina platensis sebesar 256,46 ppm dengan kategori AAI sedang. Hasil uji antioksidan sediaan yang mengandung ekstrak Spirulina platensis dan nanopartikel bentonit tidak menunjukkan adanya potensi aktivitas antioksidan. Konsentrasi PEG 400 dan Tween 80 secara berturut-turut yang digunakan untuk formula optimum sebesar 4,29\% b/b dan 6,71\% b/b.
\end{abstract}

Kata Kunci: antioksidan, nanopartikel bentonit, optimasi, sheet mask, spirulina

\section{Abstract}

Spirulina platensis contained phycocyanin that has the potential for antioxidant activity. Bentonite contains various minerals that can absorb water and was known having ability for scavenging of free radicals. The purpose of this study was to obtain the optimum formulae of sheet mask essence, containing combination of Spirulina platensis extract and bentonite nanoparticles and evaluated the antioxidant activity using DPPH (2,2-diphenyl-1-pikrihidrazil) assay. Bentonite nanoparticles was prepared by High Energy Milling (HEM) method and characterized using Particle Size Analyzer (PSA). The results of the nanoparticles characterization was $152,8 \pm 0,69 \mathrm{~nm}$ for the particle size and $0.106 \pm 0.03$ for PI value. Physical stability tests showed that the formula was homogenous, viscosity between 0.7-1.1 dPas, and pH between 5-6.5. The IC 50 value of Spirulina platensis extract was 256.46 ppm with AAI category was medium. The antioxidant test of this fomula that contain Spirulina platensis extract and bentonite nanoparticles did not show any potential antioxidant activity. The concentrations of PEG 400 and Tween 80 were used to formulate the optimum formula were $4.29 \% \mathrm{w} / \mathrm{w}$ and $6.71 \% \mathrm{w} / \mathrm{w}$.

Keywords: antioxidants, bentonite nanoparticles, optimation, sheet mask essence, spirulina

\section{PENDAHULUAN}

Kulit wajah merupakan salah satu organ yang sensitif terhadap rangsangan sehingga kulit wajah memerlukan perawatan yang khusus dibandingkan kulit bagian tubuh lainnya. Permasalahan yang sering dikeluhkan adalah kerutan sebagai akibat proses penuaan kulit. Proses penuaan dipengaruhi faktor internal seperti chronological-aging, biological-aging (genetik), catabolic-aging (penyakit kronis), dan hormonal-aging. Faktor eksternal yang mempengaruhi penuaan kulit seperti radiasi UV, environmental-aging, mechanical aging, behavioura-aging dan 
gravitational-aging (Calleja-Agius et al., 2007).

Penuaan kulit terjadi karena akumulasi kerusakan endogen yang disebabkan adanya pembentukan senyawa oksigen reaktif. Reactive Oxygen Species (ROS) yang diproduksi makhluk hidup pada konsentrasi rendah hingga sedang berfungsi dalam proses fisiologis sel namun merugikan pada komponen sel seperti lipid, protein dan DNA pada konsentrasi tinggi (Birben et al., 2012). Oksigen reaktif penyebab kerusakan tubuh ini dapat dihambat dan diperlambat dengan menggunakan antioksidan pada kadar tertentu. Fikosianin dalam Spirulina platensis memiliki sifat antioksidan dan antiradikal yang signifikan serta dapat mengikat logam berat (Bashandy et al., 2016). Fikosianin yang terkandung di dalam spirulina memiliki kecenderungan yang kuat untuk menjaga kelembaban pada kulit dan rambut, memperbaiki tekstur kulit dan kelembutan rambut (Hagino, 2010). Nilai inhibition concentration $50 \% \quad\left(\mathrm{IC}_{50}\right)$ dari spirulina sampel kering dari hasil penelitian Agustini (2015) sebesar 33,075 ppm yang menunjukkan aktivitas antioksidan yang lebih kuat dibandingkan spirulina sampel basah.

Bentonit dalam sediaan farmasi tabir surya mampu meredam radikal bebas paling tinggi pada konsentrasi 50 ppm sebesar 63,607 $\%$ dan bentonit tanpa sediaan sebesar 33,185\% (Fidiyawati dan Taufikurrohman, 2012). Bentonit digunakan sebagai bahan tambahan di berbagai industri karena kemampuan daya serap dan pengembang sehingga daya kerja bahan utama dapat meningkat. Bentonit berfungsi sebagai penyerap kotoran yang menyumbat pori-pori wajah. Suatu partikel dikatakan memiliki ukuran nano jika diameternya berkisar antara 1-1000 nm (Nagpal et al., 2010). Nanopartikel berperan penting dalam peningkatan interaksi antarpartikel yang menyebabkan peningkatan viskositas dimana nanopartikel memiliki luas permukaan yang besar dengan volume yang kecil (Al-Zubaidi et al., 2017). Penggunaan nanobentonit dalam sediaan kosmetik dapat meningkatkan kemampuan dispersi bahan baku kosmetik dalam pelarut dan ketahanan warna yang tinggi, dan ketahanan terhadap iritasi (Nugrahani dan Ismiyati, 2014).

Penerapan dan pengembangan produk masker dengan lapisan tipis kering (dry film/sheet) dinilai menguntungkan produk sehingga dapat dipotong atau dibentuk sesuai yang diinginkan dibandingkan pasta. Pasta yang mengandung bentonit sebagai basis pembersih wajah belum sepenuhnya dimanfaatkan secara efektif. Konsumen harus menggosok kulit guna menghilangkan produk tersebut. Masker yang kering tersebut cenderung jatuh dari wajah dan mengotori kamar mandi, pakaian, dan konsumen juga perlu menggunakan produk pembersih untuk membilas sisa masker (Agarwal et al., 2016), sehingga dilakukan formulasi sediaan sheet mask.

Surfaktan ionik seperti Tween 80 dipilih guna mengurangi pengaruh muatan yang dapat mempengaruhi sediaan. Tween 80 merupakan surfaktan nonionik yang memiliki risiko toksisitas lebih rendah dibandingkan dengan surfaktan lain (Rowe et al., 2006). Tween 80 diketahui mempertahankan sifat kerja pengawet dalam zat pembawanya yang dapat mengurangi absorpsi pengawet. Penggunaan kosurfaktan seperti PEG 400 dapat meningkatkan kelarutan paraben dalam pembawa sehingga penetrasi paraben ke kulit dapat dihambat (Martin et al, 2009). Penambahan kosurfaktan dapat meningkatkan penurunan tegangan antarmuka dan memfluidasi lapisan film surfaktan (Tsai et al., 2014), sehingga mempermudah proses pengembangan paper face. Campuran PEG dan Tween 80 sering digunakan untuk melarutkan obat yang kelarutannya buruk. PEG dengan bobot molekul yang tinggi diketahui menjadi miscible dengan Tween 80 pada kisaran suhu $40-70^{\circ} \mathrm{C}$ (Tejwani, R. W. et al, 2000). Dalam penelitian ini, dilakukan optimasi PEG 400 dan Tween 80 untuk mendapatkan komposisi optimum antara PEG 400 dan Tween 80 dan memenuhi sifat fisik 
sediaan sheet mask yang berupa uji organoleptik, $\mathrm{pH}$, dan viskositas.

\section{METODE PENELITIAN}

Alat

Alat yang digunakan antara lain spektrofotometer UV-Vis (UV MINI 1240 SHIMADZU), high energy milling (HEM), particle size analyzer (SZ-100 Nano Partica Horiba), furnace (Ney ${ }^{\circledR}$ Vulcan D-550), sonikator (2510 BRANSON), oven binder (Memmert), waterbath (Memmert), neraca analitik (OHAUS), kuvet (Hellma Analytics), microtube, $\mathrm{pH}$ meter (OHAUS BENCHTOP STARTER 3100), viskometer Rion VT-04E, mikropipet (Socorex), alat gelas (Pyrex), cawan porselen, rotary evaporator (Stuart), buchner (GAST), dan magnetic stirer.

\section{Bahan}

Bahan yang digunakan antara lain serbuk Spirulina platensis budidaya air tawar (Cyanovit), metanol (E. Merck), DPPH (Sigma Aldrich, p.a), bahan-bahan dengan grade teknis seperti bentonit, PEG 400, Tween 80, gliserin, propilen glikol, xanthan gum, sodium benzoat, metil paraben, propil paraben, sodium metabisulfit, $\mathrm{Na}_{2}$ EDTA, asam klorida $(\mathrm{HCl})$ p.a $37 \%$ (Merck), etanol p.a (E. Merck), dan compessed facial mask paper (USUPSO ${ }^{\circledR}$ ).

\section{Ekstraksi Spirulina platensis}

Ekstrak Spirulina platensis dibuat dengan cara maserasi menggunakan pelarut metanol. Perbandingan yang digunakan dalam maserasi Spirulina platensis dan pelarut metanol adalah 1:10. Campuran dimaserasi selama 24 jam pada suhu ruang, maserat dipisahkan dan diremaserasi sebanyak dua kali dengan pelarut yang sama dengan perbandingan 1:10 agar penyarian lebih efektif. Semua maserat yang diperoleh kemudian dipekatkan menggunakan rotary evaporator pada suhu $60^{\circ} \mathrm{C}$ dan diuapkan di atas penangas air hingga diperoleh ekstrak kental.

\section{Pembuatan Nanopartikel Bentonit dengan Metode High Energy Milling}

Proses pembuatan nanopartikel bentonit diawali dengan pemurnian bentonit dari bahan-bahan pengotor yang terdapat dalam bentonit alam dilakukan dengan menggunakan $\mathrm{HCl} 32 \%$ (10M). Serbuk bentonit sebanyak 100 gram dicampur larutan $\mathrm{HCl} 32 \%$ dengan bantuan magnetic stirer selama 90 menit. Campuran dicuci menggunakan akuades beberapa kali sampai diperoleh $\mathrm{pH}$ normal. Bentonit basah dikeringkan pada suhu $70^{\circ} \mathrm{C}$ selama 5 jam. Reduksi ikatan $\mathrm{Cl}$ pada bentonit hasil pemurnian dilakukan dengan bantuan proses kalsinasi pada suhu $600^{\circ} \mathrm{C}$. Nanopartikel bentonit diperoleh dengan proses High Energy Milling (HEM) tipe shaker selama 7 hari. Proses milling dilakukan pada $1000 \mathrm{rpm}$. Karakterisasi dilakukan dengan Particle Size Analyzer (PSA) pada suhu $25^{\circ} \mathrm{C}$ dan sudut hamburan 90 yang sebelumnya bentonit sebanyak $10 \mathrm{mg}$ bentonit telah didispersikan dalam $5 \mathrm{~mL}$ aqua pro injeksi.

\section{Formulasi Esens Sheet Mask}

Formula esens sheet mask dapat dilihat pada Tabel 1. Esens dibuat dengan mencampurkan Tween 80 dan PEG 400 sebagai campuran A. Metil paraben dan propil paraben dilarutkan dalam propilen glikol (campuran B). Ekstrak spirulina dilarutkan terlebih dahulu dengan etanol $70 \%$. Bentonit didispersikan dalam akuades sebagai campuran C. Campuran B dan C dicampurkan ke dalam campuran A yang selanjutnya ditambahkan bahan-bahan lain sesuai dengan Tabel 1 dan ekstrak yang telah larut. Penambahan akuades dilakukan hingga mencapai berat 100 gram, kemudian diaduk hingga homogen. Esens yang telah diperoleh diletakkan di dalam jar kemudian compessed facial mask paper dimasukkan ke dalam jar yang berisi esens.

\section{Uji Sifat Fisik Esens}

Uji sifat fisik berupa pengamatan organoleptik, $\mathrm{pH}$ dan viskositas dilakukan selama 4 minggu.

\section{Optimasi Formula}

Optimasi dilakukan dengan menggunakan software Design Expert versi 11 (trial) dengan metode Simplex Lattice Design (SLD) dengan memasukkan hasil 
Tabel 1. Formula esens sheet mask kombinasi ekstrak spirulina dan nano bentonit

\begin{tabular}{lccccc}
\hline Bahan & F1 $(\mathrm{g})$ & $\mathrm{F} 2(\mathrm{~g})$ & $\mathrm{F} 3(\mathrm{~g})$ & $\mathrm{F} 4(\mathrm{~g})$ & $\mathrm{F} 5(\mathrm{~g})$ \\
\hline Ekstrak Spirulina & 2 & 2 & 2 & 2 & 2 \\
platensis & & & & & \\
Bentonit & 0,3 & 0,3 & 0,3 & 0,3 & 0,3 \\
PEG 400 & 1 & 3,25 & 5,5 & 7,75 & 10 \\
Tween 80 & 10 & 7,75 & 5,5 & 3,25 & 1 \\
Gliserin & 5 & 5 & 5 & 5 & 5 \\
Propilen Glikol & 5 & 5 & 5 & 5 & 5 \\
Xanthan Gum & 0,3 & 0,3 & 0,3 & 0,3 & 0,3 \\
Sodium Benzoat & 0,5 & 0,5 & 0,5 & 0,5 & 0,5 \\
Metil Paraben & 0,18 & 0,18 & 0,18 & 0,18 & 0,18 \\
Propil Paraben & 0,02 & 0,02 & 0,02 & 0,02 & 0,02 \\
Sodium Metabisulfit & 0,1 & 0,1 & 0,1 & 0,1 & 0,1 \\
Na 2 EDTA & 0,1 & 0,1 & 0,1 & 0,1 & 0,1 \\
Akuades & ad 100 & ad 100 & ad 100 & ad 100 & ad 100 \\
\hline
\end{tabular}

pengujian $\mathrm{pH}$ dan viskositas dari kelima sediaan yang telah diuji. Formula optimum yang diperoleh diuji kembali sifat fisiknya dan hasil yang diperoleh dibandingkan dengan point prediction hasil Simplex Lattice Design. Verifikasi hasil dianalisis dengan uji t-One Sample.

\section{Uji Aktivitas Antioksidan}

Ditimbang kurang lebih $15,80 \mathrm{mg}$ serbuk DPPH dan dilarutkan hingga mencapai 100,0 $\mathrm{mL}$ dengan etanol p.a sehingga diperoleh konsentrasi 0,4 mM. Larutan dicampurkan hingga homogen dengan bantuan sonikator dan disimpan pada suhu rendah dan terhindar dari cahaya matahari. Larutan DPPH dibaca sebagai blanko pada $\lambda$ maksimal $516,5 \mathrm{~nm}$.

Sebanyak 20,0 mg vitamin E dilarutkan dengan etanol p.a hingga mencapai $10,0 \mathrm{~mL}$ yang digunakan sebagai kontrol positif dengan konsentrasi akhir $1000 \mathrm{ppm}(1000 \mu \mathrm{g} / \mathrm{mL})$. Larutan stok diencerkan menjadi 120 ppm $(120 \mu \mathrm{g} / \mathrm{mL})$ dengan mengambil sebanyak 90 $\mu \mathrm{L}$ ditambahkan etanol p.a hingga mencapai $1500 \mu \mathrm{L}$. Larutan 120 ppm diencerkan dengan menggunakan metode serial delution sehingga diperoleh konsentrasi akhir 60 ppm, 30 ppm, 15 ppm, dan 7,5 ppm. Masing-masing dari kelima seri konsentrasi ini diambil sebanyak $500 \mu \mathrm{L}$, ditambahkan $500 \mu \mathrm{L}$ larutan DPPH 0,4 mM dan etanol p.a hingga $1500 \mu \mathrm{L}$ ke dalam microtube sehingga konsentrasi akhir larutan adalah 40 ppm, 20 ppm, 10 ppm, 5 ppm, dan 2,5 ppm. Larutan diinkubasi dalam ruangan gelap selama 30 menit. Serapan diukur pada $\lambda$ 516,5 $\mathrm{nm}$ dengan spektrofotometer UV-Vis. Preparasi seri konsentrasi dilakukan sebanyak 3 kali.

Ekstrak Spirulina ditimbang sebanyak 50,0 mg dilarutkan dengan etanol 70\% sampai batas tanda pada labu takar $25 \mathrm{~mL}$ sehingga konsentrasi akhir larutan 2.000 ppm (2.000 $\mu \mathrm{g} / \mathrm{mL})$. Larutan stok diambil $900 \mu \mathrm{L}$ dan ditambahkan etanol p.a hingga batas $1500 \mu \mathrm{L}$ pada microtube untuk mendapatkan konsentrasi 1200 ppm. Larutan 1200 ppm diencerkan kembali menggunakan metode serial dilution untuk mendapatkan seri konsentrasi 600 ppm, 300 ppm, 150 ppm, dan 75 ppm. Kelima seri konsentrasi masingmasing diambil $500 \mu \mathrm{L}$, ditambahkan $500 \mu \mathrm{L}$ larutan DPPH 0,4 $\mathrm{mM}$ dan etanol p.a hingga $1500 \mu \mathrm{L}$ ke dalam microtube. Larutan akhir memiliki konsentrasi 400 ppm, 200 ppm, 100 ppm, 50 ppm, dan 25 ppm diinkubasi dalam ruangan gelap selama 30 menit. Serapan diukur pada $\lambda$ maksimal dengan 
spektrofotometer UV-Vis. Preparasi seri konsentrasi dilakukan sebanyak 3 kali.

Formula optimum dan basis dibuat konsentrasi $20.000 \quad \mathrm{ppm}(20.000 \mu \mathrm{g} / \mathrm{mL})$ dengan cara ditimbang sebanyak $1 \mathrm{~g}$ dilarutkan dengan akuades sampai batas tanda pada labu takar 50,0 mL. Larutan stok diencerkan dengan akuades menjadi 2.000 ppm. Larutan 2.000 ppm diencerkan kembali menggunakan metode serial delution untuk mendapatkan seri konsentrasi 1.200 ppm, 600 ppm, 300 ppm, 150 ppm, dan 75 ppm. Kelima seri konsentrasi masing-masing diambil 500 $\mu \mathrm{L}$, ditambahkan $500 \mu \mathrm{L}$ larutan DPPH 0,4 $\mathrm{mM}$ dan etanol p.a hingga $1500 \mu \mathrm{L}$ ke dalam microtube. Konsentrasi larutan akhir yang diperoleh yakni 400 ppm, 200 ppm, 100 ppm, 50 ppm dan 25 ppm. Larutan diinkubasi dalam ruangan gelap selama 30 menit. Serapan diukur pada $\lambda$ maksimal dengan spektrofotometer UV-Vis. Preparasi seri konsentrasi dilakukan sebanyak 3 kali.

Besar persen penghambatan dihitung berdasarkan rumus dari (Da'i and Triharman, 2010) seperti pada persamaan 1 .

$\%$ penghambatan $=$

$\underline{\text { abs. larutan DPPH -(abs. sampel-abs. kontrol) }} \times 100 \%$ (1)

Konsentrasi sampel dan persen penghambatan diplotkan masing-masing pada sumbu $x$ dan y dengan cara regresi linear. Persamaan kurva baku yang diperoleh digunakan untuk menghitung IC $_{50}$ sebagai nilai x dengan mengganti nilai y menjadi 50 . Kategori penentuan nilai AAI diperoleh dengan membagi konsentrasi DPPH (ppm) dengan nilai $\mathrm{IC}_{50}(\mathrm{ppm})$.

\section{HASIL DAN PEMBAHASAN}

Hasil maserasi dari serbuk Spirulina plantesis diperoleh ekstrak kental sebanyak 67,83 gram dengan rendemen $13,57 \%$. Perhitungan rendemen menunjukkan tingkat kelarutan dan mobilitas partikel yang berpengaruh pada interaksi antara sampel dan pelarut yang digunakan (Suzery et al., 2012).
Maserasi dipilih karena kemudahan, proses yang sederhana dan biaya yang lebih murah. Pemilihan metanol sebagai pelarut maserasi karena kemampuan melarutkan solute yang lebih tinggi dibandingkan etanol sehingga dapat mengekstrak spirulina lebih baik (Fithriani et al., 2015).

Pembuatan nanopartikel bentonit menghasilkan nanopartikel sebesar 88,87 gram dan rendemen 49,37\%. Nanopartikel bentonit berwarna cokelat muda dan bertekstur lembut namun juga terdapat beberapa gumpalan bentonit yang keras seperti Gambar 1.

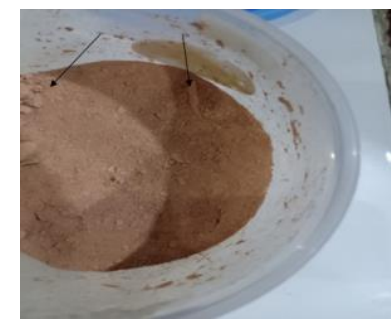

\section{Gambar 1. Hasil preparasi nanopartikel bentonit dengan metode HEM}

Gumpalan-gumpalan tersebut terjadi akibat proses agglomeration dan cold welding. Hal ini terjadi karena proses awal milling mengakibatkan sampel mengalami proses pematahan partikel sampai berukuran kecil dan terjadi kompresi sehingga sampel menjadi gumpalan (Krisnawan, 2009). Ratarata ukuran partikel yang diperoleh adalah $152,8 \pm 0,69 \mathrm{~nm}$ dengan nilai Polydispersity Index (PI) sebesar 0,106 $\pm 0,03$ yang menunjukkan bahwa bentonit yang telah dibuat termasuk dalam range ukuran nanopartikel. Hasil yang didapat menunjukkan ukuran yang lebih besar dibandingkan dengan nanopartikel bentonit yang disintesis dengan metode ko-presipitasi, dengan rata-rata ukuran partikel adalah $35 \mathrm{~nm}$ (Sirait et al., 2017).

Hasil formulasi dari kelima formula menunjukkan persamaan bentuk sediaan semisolid berupa cairan kental. Uji sifat fisik yang berupa organoleptik, $\mathrm{pH}$, dan viskositas ditampilkan pada Tabel 2 . 
Tabel 2. Hasil pengamatan organoleptik esens sheet mask kombinasi ekstrak spirulina dan nano bentonit selama 4 minggu

\begin{tabular}{|c|c|c|c|c|c|}
\hline $\begin{array}{c}\text { Parameter } \\
\text { organoleptik }\end{array}$ & F1 & $\mathrm{F} 2$ & F3 & F4 & F5 \\
\hline Tekstur & Cair, kental & Cair, kental & Cair, kental & Cair, kental & Cair, kental \\
\hline Warna & Hijau pekat & Hijau pekat & Hijau pekat & Hijau pekat & Hijau pekat \\
\hline $\mathrm{Bau}$ & Bau khas alga & Bau khas alga & Bau khas alga & Bau khas alga & Bau khas alga \\
\hline Homogenitas & Homogen & Homogen & Homogen & Homogen & Homogen \\
\hline
\end{tabular}

Pengamatan organoleptik menunjukkan sediaan esens yang dibuat memiliki sifat semisolid dengan tingkat kekentalan rendah, homogen, berwarna hijau pekat khas ekstrak spirulina. Sediaan esens tersebut mampu mempertahankan stabilitas organoleptik selama 4 minggu penyimpanan.

Uji $\mathrm{pH}$ bertujuan untuk mengetahui tingkat keasaman sediaan dan berhubungan dengan iritasi kulit. Jika $\mathrm{pH}$ tidak sesuai dengan $\mathrm{pH}$ kulit akan meningkatkan risiko iritasi dan adanya rasa tidak nyaman pada kulit wajah. Berdasarkan Tabel 2 hasil pengujian pH pada sediaan F1, F3, dan F5 memberikan hasil yang aman bagi kulit dengan rentang $\mathrm{pH}$ 5,0-5,9. Pada sediaan F2 dan F4 dinyatakan tidak aman bagi kulit dengan hasil $\mathrm{pH}$ di atas 6,5. Hal ini dikarenakan masker yang aman memiliki $\mathrm{pH}$ antara 4,5-6,5 yang ideal untuk sediaan topikal (Zhelsiana et al., 2016). Sediaan topikal yang diaplikasikan pada kulit jika lebih kecil dari 4,5 (terlalu asam) dapat menimbulkan iritasi kulit dan pada rentang $\mathrm{pH}$ yang melebihi 6,5 (terlalu basa) menyebabkan kulit bersisik (Rahmawanty et al., 2015). Peningkatan $\mathrm{pH}$ sediaan setelah 4 minggu penyimpanan kemungkinan disebabkan oleh berkurangnya kadar air yang menyebabkan berubahnya komposisi esens sheet mask.

Pengujian viskositas diperoleh rentang untuk semua formula berkisar antara 0,7-1,4 dPa.s. Sediaan F1 memiliki viskositas yang paling tinggi pada pengujian selama 4 minggu dibandingkan sediaan lainnya. Viskositas yang cukup tinggi pada sediaan F3 ini dipengaruhi tingginya konsentrasi Tween 80 dan PEG 400 paling rendah dibanding sediaan lainnya. Hal ini sesuai dengan penyataan
Koocheki dan Kadkhodaee (2011), peningkatan konsentrasi Tween 80 akan meningkatkan viskositas. Penambahan Tween 80 yang semakin banyak menyebabkan sistem dispers semakin rigid. Medium dispers yang semakin rigid menyebabkan peningkatan viskositas dalam sistem dispers (Laverius, 2011). Penambahan surfaktan seperti Tween 80 pada kadar rendah membantu penurunan tegangan antarmuka dan meningkatkan kelarutan obat sedangkan pada kadar tinggi menyebabkan terjadinya agregasi. Penambahan gelling agent seperti xantan gum dapat meningkatkan viskositas sediaan. Namun hal ini dapat diabaikan karena penggunaan xantan gum pada semua formula sama. Tinggi rendahnya viskositas sediaan yang dibuat berpengaruh pada paper face untuk mengembang dan pelepasan zat aktif dari basisnya. Viskositas yang tinggi menyebabkan sulitnya sediaan diserap paper face.

Hasil pengujian variabel terikat berupa uji $\mathrm{pH}$ dan viskositas yang digunakan untuk menentukan konsentrasi PEG 400 dan Tween 80 pada formula optimum dengan menggunakan metode Simplex Lattice Design ditunjukkan pada Tabel 3.

Tabel 3 menunjukkan hasil pengujian sifat fisik kelima sediaan pada minggu pertama. Uji $\mathrm{pH}$ bertujuan untuk mengetahui tingkat keasaman sediaan dan berhubungan dengan iritasi kulit. Jika $\mathrm{pH}$ tidak sesuai dengan $\mathrm{pH}$ kulit akan meningkatkan risiko iritasi dan adanya rasa tidak nyaman pada kulit wajah. Berdasarkan 3 hasil pengujian $\mathrm{pH}$ pada 
Tabel 3. Hasil pengujian sifat fisik sediaan esens sheet mask kombinasi ekstrak spirulina dan nanobentonit pada minggu pertama

\begin{tabular}{ccc}
\hline Formula & $\mathrm{pH}$ & $\begin{array}{c}\text { Viskositas } \\
(\mathrm{dPa} . \mathrm{s})\end{array}$ \\
\hline 1 & $5,11 \pm 0,08$ & $0,90 \pm 0,00$ \\
2 & $6,82 \pm 0,02$ & $0,97 \pm 0,06$ \\
3 & $5,86 \pm 0,04$ & $0,87 \pm 0,06$ \\
4 & $6,65 \pm 0,02$ & $0,87 \pm 0,06$ \\
5 & $5,11 \pm 0,04$ & $1,13 \pm 0,06$ \\
\hline
\end{tabular}

sediaan F1, F3, dan F5 memberikan hasil yang aman bagi kulit dengan rentang $\mathrm{pH}$ 5,0-5,9.

Pada sediaan F2 dan F4 dinyatakan tidak aman bagi kulit dengan hasil $\mathrm{pH}$ di atas 6,5. Hal ini dikarenakan masker yang aman memiliki $\mathrm{pH}$ antara 4,5-6,5 yang ideal untuk sediaan topikal (Zhelsiana et al., 2016). Sediaan topikal yang diaplikasikan pada kulit jika lebih kecil dari 4,5 (terlalu asam) dapat menimbulkan iritasi kulit dan pada rentang $\mathrm{pH}$ yang melebihi 6,5 (terlalu basa) menyebabkan kulit bersisik (Rahmawanty et al., 2015). Pengujian $\mathrm{pH}$ pada kelima sediaan tersebut diketahui bahwa F2 dan F4 tidak memenuhi $\mathrm{pH}$ sediaan topikal menurut ketentuan Farmakope Indonesia, yaitu antara 5-6,5. Bahan yang diduga menyebabkan $\mathrm{pH}$ tinggi pada F2 dan F4 adalah PEG 400. PEG 400 diketahui memiliki $\mathrm{pH}$ pada rentang 5,0-7,0 (Rowe et al., 2006). Selain hal tersebut, pengujian viskositas menunjukkan F5 merupakan sediaan paling kental dibanding formula lain.

Hasil analisis uji respon $\mathrm{pH}$ minggu pertama diperoleh model plot SLD ditunjukkan pada Gambar 2. Gambar 2 menunjukkan contour plot $\mathrm{pH}$ sediaan dengan persamaan yang menghasilkan grafik quadratic. Pengujian $\mathrm{pH}$ menentukan keamanan sediaan yang dibuat dengan rentang 4,5-6,5. Persamaan SLD pH sediaan diperoleh $\mathrm{Y}=5,27 \mathrm{~A}+5,20 \mathrm{~B}+5,43 \mathrm{AB}$ dengan koefisien interaksi positif antara Tween 80 dan PEG 400 sebesar $+5,43$ yang meningkatkan $\mathrm{pH}$ sediaan. Perolehan uji ANOVA pada evaluasi respon pH menggunakan persamaan Scheffé menunjukkan sebesar 0,3926 yang lebih besar

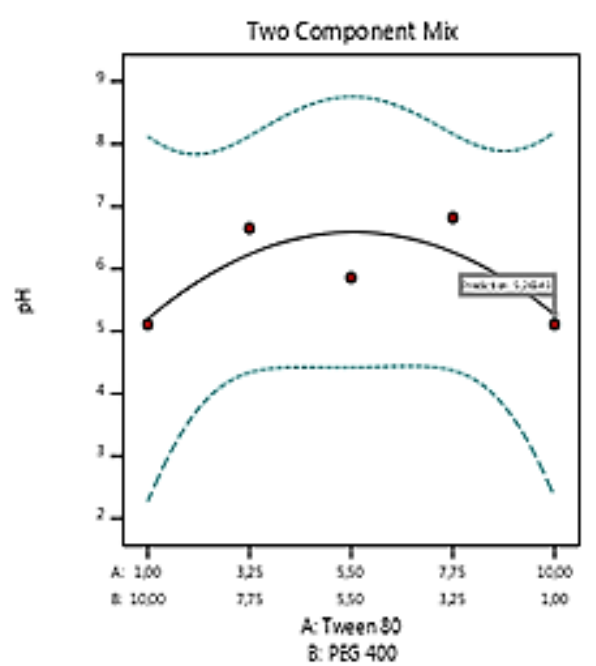

Gambar 2. Contour plot pH esens sheet mask dari kelima formulasi kombinasi ekstrak spirulina dan nanobentonit dari kelima formulasi

dibandingkan $p$-value $<0,05$ sehingga persamaan tersebut tidak signifikan dalam memperkirakan pola sebaran data $\mathrm{pH}$.

Analisis menggunakan software Simplex Lattice Design (SLD) untuk menentukan formula optimum diperoleh model plot respon viskositas seperti Gambar 3.

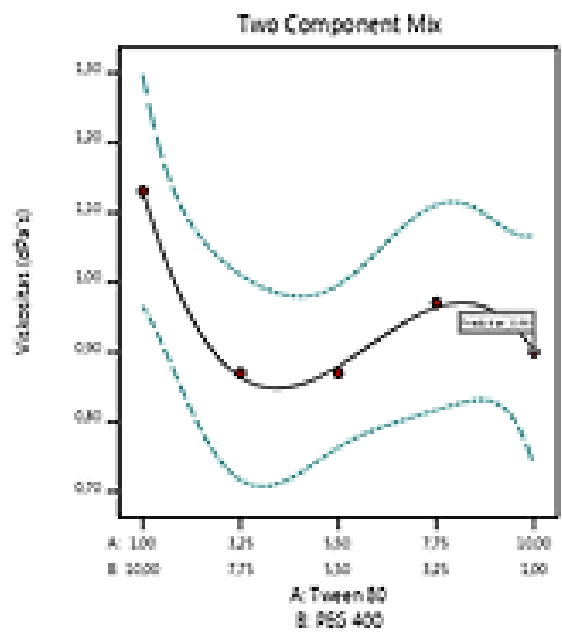

Gambar 3. Contour plot viskositas sediaan esens sheet mask kombinasi ekstrak spirulina dan nanobentonit dari kelima formulasi 
Gambar 3 menunjukkan contour plot viskositas sediaan yang menghasilkan grafik cubic. Berdasarkan persamaan viskositas sediaan diperoleh $\mathrm{Y}=0,9016 \mathrm{~A}+1,13 \mathrm{~B}-$ 0,5486AB dengan koefisien interaksi bernilai negatif sebesar -0,5486. Interaksi negatif antara Tween 80 dan PEG 400 menunjukkan adanya pengaruh terhadap penurunan viskositas sediaan. Gambar 2 menunjukkan viskositas sediaan lebih banyak dipengaruhi konsentrasi PEG 400 dibandingkan Tween 80 pada perbandingan 10:1. Viskositas minggu pertama diperoleh hasil yang tidak sesuai dibandingkan spesifikasi masing-masing surfaktan dimana viskositas Tween 80 sebesar 425 mPa's dan PEG 400 sebesar 105-130 mPa's (Rowe et al., 2006).

Perolehan uji ANOVA pada evaluasi respon viskositas menggunakan persamaan Scheffé menunjukkan sebesar 0,0763 yang lebih besar dibandingkan p-value $<0,05$ sehingga persamaan tersebut tidak signifikan dalam memperkirakan pola sebaran data viskositas.

Desirability tertinggi yang diperoleh dari software adalah 0,855 pada solution 1 dari total 3 solution. Nilai maksimal dari desirability adalah satu. Semakin mendekati satu maka desirability tersebut semakin baik (Suryani dan Nafisah, 2017). Perbandingan PEG 400 dan Tween 80 serta hasil uji sifat fisik yang diperoleh dari point prediction ditunjukkan pada Tabel 4.

\begin{tabular}{cccc}
$\begin{array}{c}\text { Tabel 4. Prediksi respon serta konsentrasi } \\
\text { PEG 400 dan Tween } \\
\text { 80 pada formula } \\
\text { optimum }\end{array}$ & \\
\hline Bahan & Konsentrasi & $\mathrm{pH}$ & $\begin{array}{c}\text { Viskositas } \\
\text { (dPa.s) }\end{array}$ \\
\hline PEG 400 & $\begin{array}{l}4,29 \% \\
6,71 \%\end{array}$ & 6,5 & 0,93 \\
Tween 80 & & & \\
\hline
\end{tabular}

Perbandingan yang diperoleh dari prediksi respon software menunjukkan prediksi $\mathrm{pH}$ yang memenuhi rentang $\mathrm{pH}$ kulit wajah dan viskositas yang tidak terlalu tinggi sehingga mempermudah proses pengembangan paper face.

Hasil pengujian sifat fisik formula optimum yang diperoleh dibandingkan dengan hasil prediksi Simplex Lattice Design dengan analisis statistik dijabarkan pada Tabel 5 .

Hasil uji-t One Sample pada Tabel 5 menunjukkan bahwa formula optimum tidak memiliki pengaruh yang signifikan terhadap respon viskositas. Respon $\mathrm{pH}$ memiliki $\mathrm{p}$ value $<0,05$ yang berarti formula optimum signifikan berpengaruh dalam memprediksi $\mathrm{pH}$. Hasil analisis tersebut menunjukkan formula optimum yang telah dibuat valid digunakan sebagai pengoptimasi sediaan karena rentang $\mathrm{pH}$ terpenuhi dan viskositas sediaan sebesar 0,868 tersebut dapat mengembangkan paper face.

Hasil pengujian aktivitas antioksidan vitamin E, ekstrak Spirulina platensis, formula optimum dan basis formula pada ditampilkan pada Tabel 6. Berdasarkan perolehan nilai IC50 dan AAI, vitamin E termasuk golongan antioksidan yang sangat kuat. Ekstrak spirulina yang digunakan sebagai bahan baku utama formulasi memiliki kategori antioksidan sedang berdasarkan nilai AAI sebesar 0,62 $\pm 0,05$ (Molyneux, 2004). Pengujian aktivitas antioksidan formula optimum yang mengandung ekstrak spirulina dan nanopartikel bentonit menunjukkan adanya aktivitas antioksidan yang sangat lemah sehingga hanya memiliki sedikit kemampuan dalam menghambat senyawa radikal. Aktivitas antioksidan formula

Tabel 5 Verifikasi Hasil Optimasi Menggunakan Uji-t One Sample

\begin{tabular}{ccccc}
\hline Respon & Percobaan & Prediksi & Signifikansi & Kesimpulan \\
\hline Viskositas & $0,9 \pm 0,000$ & 0,93 & 0,868 & Berbeda tidak signifikan \\
pH & $5,10 \pm 0,076$ & 6,5 & 0,010 & Berbeda signifikan \\
\hline
\end{tabular}


Tabel 6. Hasil uji antioksidan esens sheet mask kombinasi ekstrak spirulina dan nanobentonit

\begin{tabular}{|c|c|c|c|}
\hline Sampel & $\mathrm{IC}_{50} *$ & AAI* & Keterangan** \\
\hline Vit, E & $19,64 \pm 2,48$ & $8,14 \pm 1,05$ & Sangat kuat \\
\hline Ekstrak Spirulina & $256,45 \pm 20,77$ & $0,62 \pm 0,05$ & Sedang \\
\hline Formula optimum & $735,48 \pm 645,62$ & $0,18 \pm 0,17$ & Sangat lemah \\
\hline Basis formula optimum & $755,03 \pm 90,54$ & $0,21 \pm 0,02$ & Sangat lemah \\
\hline
\end{tabular}

optimum yang lebih rendah dibandingkan ekstrak spirulina disebabkan penggunaan ekstrak spirulina dalam sediaan hanya $2 \% \mathrm{~b} / \mathrm{b}$ sedangkan ekstrak spirulina sebagai pembanding sebesar $100 \% \mathrm{~b} / \mathrm{b}$. Hasil ini berbeda dibandingkan penelitian sebelumnya di mana pada kadar $0,02 \%$ b/v, ekstrak methanol spirulina menunjukkan penghambatan radikal sebesar $89 \%$ (Shalaby and Shanab, 2013). Faktor lain yang berpengaruh terhadap aktivitas antioksidan adalah pengaruh cahaya yang dapat menyebabkan penurunan aktivitas antioksidan dan kemungkinan adanya adsorpsi zat aktif dalam dalam ekstrak spirulina oleh nanopartikel bentonit.

\section{KESIMPULAN}

Berdasarkan hasil penelitian dapat disimpulkan bahwa hasil sintesis nanopartikel bentonit dengan alat High Energy Milling tipe shaker diperoleh ukuran partikel sebesar $152,8 \pm 0,69 \mathrm{~nm}$ dengan nilai Polydispersity
Index (PI) 0,106 $\pm 0,03$. Konsentrasi PEG 400 dan Tween 80 secara berturut-turut yang digunakan untuk memformulasi formula optimum sebesar $4,29 \% \mathrm{~b} / \mathrm{b}$ dan $6,71 \% \mathrm{~b} / \mathrm{b}$ dapat digunakan sebagai pengoptimasi sediaan esens sheet mask dan diperoleh sediaan yang stabil melalui uji organoleptik, $\mathrm{pH}$, dan viskositas. Uji aktivitas antioksidan pada formula optimum kombinasi ekstrak spirulina dan nanopartikel bentonit menunjukkan aktivitas antioksidan yang sangat lemah dengan metode penangkapan radikal bebas menggunakan DPPH. Formulasi optimum esens sheet mask dapat dikembangkan lebih lanjut agar mempunyai aktivitas antioksidan dan antibakterial yang optimum.

\section{UCAPAN TERIMA KASIH}

Terima kasih penulis ucapkan kepada Universitas Muhammadiyah Surakarta yang telah membiayai penelitian ini melalui skema PID.

\section{Daftar Pustaka}

Al-Zubaidi N.S., Alwasiti A.A. and Mahmood D., 2017, A comparison of nano bentonite and some nano chemical additives to improve drilling fluid using local clay and commercial bentonites, Egyptian Journal of Petroleum, 26 (3), 811-818.

Bashandy S.A.E., El Awdan S.A., Ebaid H. and Alhazza I.M., 2016, Antioxidant Potential of Spirulina platensis Mitigates Oxidative Stress and Reprotoxicity Induced by Sodium Arsenite in Male Rats, Oxidative Medicine and Cellular Longevity, 2016

Birben E., Sahiner U.M., Sackesen C., Erzurum S. and Kalayci O., 2012, Oxidative Stress and Antioxidant Defense, WAO Journal, 9-19.

Calleja-Agius J., Muscat-Baron Y. and Brincat M.P., 2007, Skin ageing, Menopause Int, 13 
(2), 60-64.

Da'i M. and Triharman F., 2010, Uji Aktivitas Penangkap Radikal DPPH (1,1-difenil-2pikrilhidrazil) Isolat Alfa Mangostin Kulit Buah Manggis (Garcinia mangostana L.), , 11 (2), 47-50.

Krisnawan A., 2009, Karakterisasi Sampel Paduan Magnesium Jenis Az9 1D Dengan Berbagai Variasi Waktu Milling Menggunakan X-Ray Fluoresence (Xrf) Dan X-Ray Difraction (Xrd) Program Studi Fisika Fakultas Sains Dan Teknologi Universitas Islam Negeri Syarif Hidayatullah Jakarta

Nagpal K., Singh S.K. and Mishra D.N., 2010, Chitosan Nanoparticles: A Promising System in Novel Drug Delivery, C, 58 (11), 1423-1430.

Rahmawanty D., Yulianti N. and Fitriana M., 2015, Formulasi dan Evaluasi Masker Wajah Peel Off Mengandung Kuersetin dengan Variasi Konsentrasi Gelatin dan Gliserin, Media Farmasi, 12 (1), 17-32.

Scherer R. and Godoy H.T., 2009, Antioxidant activity index (AAI) by the 2,2-diphenyl-1picrylhydrazyl method, Food Chemistry, 112 (3), 654-658.

Shalaby E. and Shanab S., 2013, Comparison of DPPH and ABTS assays for determining antioxidant potential of water and methanol extracts of Spirulina platensis, Indian J. GeoMar. Sci

Sirait M., Bukit N. and Siregar N., 2017, Preparation and characterization of natural bentonite in to nanoparticles by co-precipitation method, Dalam p. 020006.

Suryani S., Nafisah A. and Mana'an S., 2017, Optimasi Formula Gel Antioksidan Ekstrak Etanol Buah Bligo ( Benincasa hispida ) dengan Metode Simplex Lattice Design ( SLD ), , 3 (2), 150-156.

Suzery M., Lestari S. and Cahyono B., 2012, Penentuan Total Antosianin Dari Kelopak Bunga Rosela (Hibiscus sabdariffa L.) dengan Metode Maserasi dan Sokhletasi, Jurnal Sains \& Matematika, 18, 1-6. 